\begin{tabular}{|c|c|}
\hline$E$ & 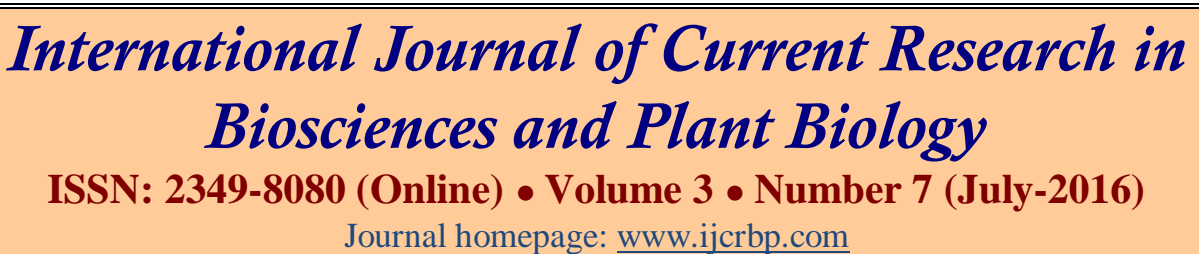 \\
\hline
\end{tabular}

\title{
A Comparative Study of Vermicompost Prepared from Phytoremediated and Naturally Grown Aquatic Weeds on Growth and Yield of Green Gram [Vigna radiata (L.) Wilczek]
}

\author{
Monica Mishra ${ }^{1}$, Ashirbad Mohapatra² and Kunja Bihari Satapathy ${ }^{*}$ \\ ${ }^{1}$ Post Graduate Department of Botany, Utkal University, Vani Vihar, Bhubaneswar-751004, Odisha \\ ${ }_{2}^{2}$ Sri Jayadev College of Education and Technology, Naharkanta, Bhubaneswar-752101, Odisha, India
}

*Corresponding author.

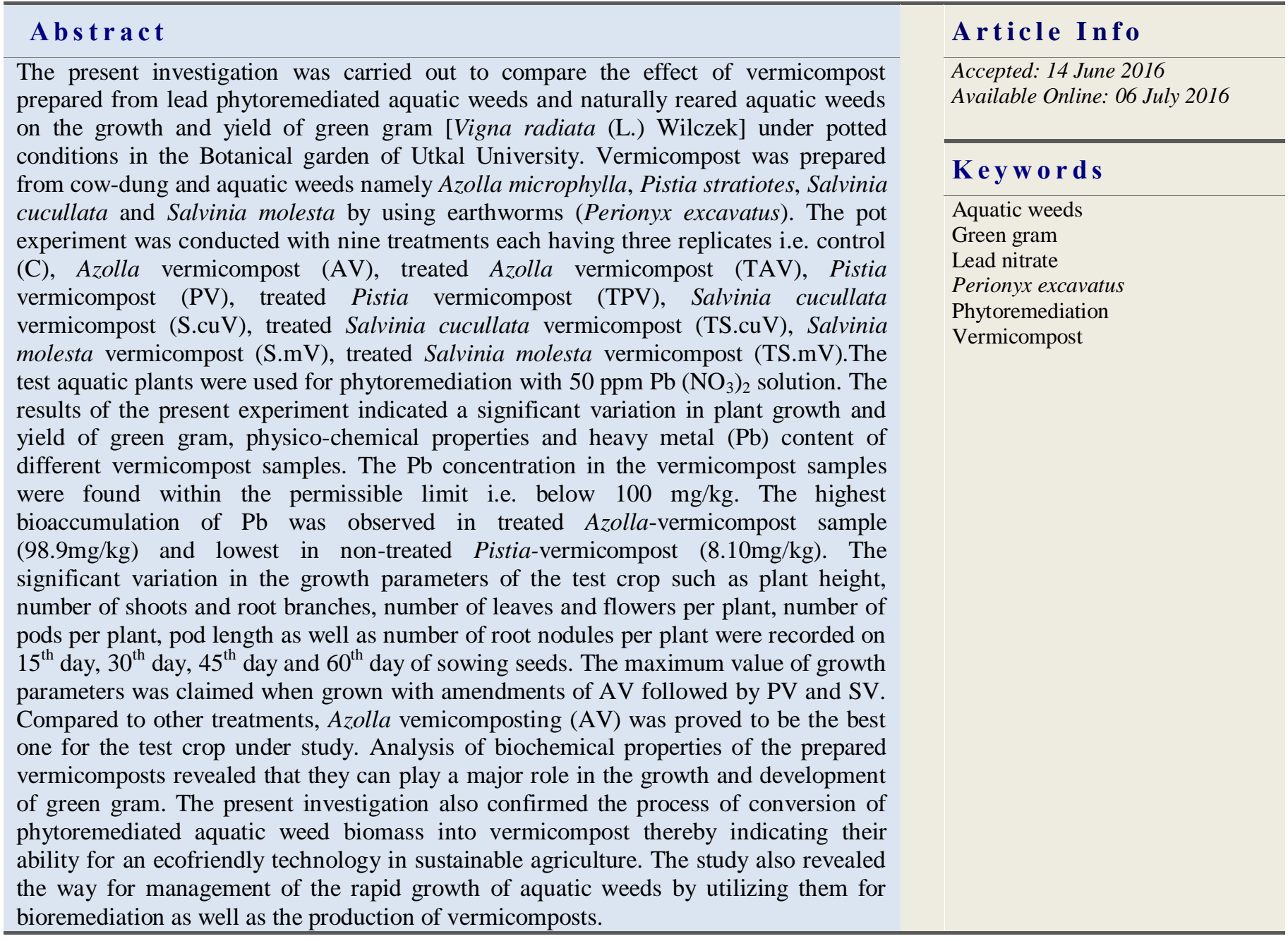




\section{Introduction}

The demand of food has doubled with increasing population of the world which inundated the available land resources (Hussain et al., 2011). The need of increased food production in most developing countries has become the ultimate goal to meet the demand of dramatic expansion of their population (EI-Shaikh and Mohammed, 2009). Among the major food crops, pulses are considered as one of the most important one in terms of cultivation and consumption. Pulse crops have been shown to be an excellent source of dietary protein used in the human diet and play a key role in crop rotation due to their ability for fixation of nitrogen (Saminathan, 2013). Generally, pulses are cultivated in all parts of the world by using different inputs like chemical fertilizers and pesticides. In recent days, the use of different organic fertilizers, biofertilizers and biopesticides are being recommended not only to minimize the use of hazardous chemical inputs but also for sustainable crop production.

Rapid industrialization, urbanization and increase in population in the last few decades have added huge loads of pollutants in the water resources (CPCB, 2008). Among various water pollutants, heavy metals are of major concern because of their persistent and bioaccumulative nature (Rai et al., 1981). Lead $(\mathrm{Pb})$ is one of the potent toxic heavy metal that not only accumulates in individual but also have the ability to affect the entire food chain and disrupt the health system of human beings, animals and phytoplankton (Leela et al., 2010). Hence, proper treatment to remove $\mathrm{Pb}$ from soil and industrial wastewater is very important. The phytoremediation technology is suitable to be applied in treating the industrial wastewater since it is an emerging clean up technology for contaminated soils, ground water and wastewater as a low cost technique (Hinchman et al., 1996). Several studies have shown that aquatic plants are very effective in removing heavy metals from polluted water. The use of aquatic weeds such as Azolla, Pistia and Salvinia has shown about 90-98 \% removal of lead from polluted aquatic resources (Divya et al., 2011). After phytoremediation these plant materials may be burnt followed by recycling of the metals or as disposal in a landfill (Angle and Linacre, 2005).

Vermicomposting involves the bio-oxidation and stabilization of organic material by the joint action of earthworms and microorganisms (Dominguez et al., 1997). The organic carbon in vermicompost releases the nutrients slowly and steadily into the system and enables the plant to absorb nutrients. The soil enriched with vermicompost provides additional substances that are not found in chemical fertilizers (Kale et al., 1992). So the present study was carried out to examine the effect of vermicompost prepared from phytoremediated and naturally grown aquatic weeds such as Azolla microphylla, Pistia stratiotes, Salvinia molesta and Salvinia cucullata on growth and yield of green gram [Vigna radiata (L.) Wilczek].

\section{Materials and methods}

Earthworm species, Perionyx excavatus was obtained from soil testing laboratory, Sahidnagar, Bhubaneswar, Odisha and maintained in a rearing box by feeding with cow-dung for further studies. Common aquatic weeds such as Azolla microphylla Kauf., Pistia stratiotes L., Salvinia molesta D. Mitch. and Salvinia cucullata Roxb. ex Bory were collected from water bodies located in and around Bhubaneswar, the capital city of Odisha. The fresh aquatic weeds were washed with tap water and $10 \mathrm{~g}$ of each plant was exposed to $50 \mathrm{ppm}$ lead nitrate $\mathrm{Pb}$ $\left(\mathrm{NO}_{3}\right)_{2}$ solutions for 15 days, each having three replicates. It was found that about $90-95 \%$ of metal being bioaccumulated by these aquatic weeds (Mishra et al., 2015). Then equal volume of both fresh and phytoremediated aquatic weeds were chopped into small pieces and were fed to the earthworms during vermicomposting.

\section{Preparation of vermicompost unit}

Vermicomposting units were prepared on clay pots, sized 12 inch height and 9 inch width. The clay pots were filled with some pebbles and sand followed by dried cow-dung up to $1 / 4^{\text {th }}$ of pot height for providing shelter to earthworms and for maintaining moisture. Then the aquatic weeds were mixed with 30 days old cow-dung and some garden soil at 1:2:1 ratio and filled in the pots up to the top individually with uniform biomass weight. Simultaneously, only cow-dung and soil in equal proportion was also filled in pots as control. Moisture was adjusted to $50-60 \%$ and 25 numbers of both adult and juvenile earthworms (Perionyx excavatus) from rearing box were transferred to each vermipot and covered with jute gunny sheets, and kept under complete shade. Moisture was maintained regularly by spraying water. The formation of vermicasting was observed after 15 days from the date of inoculating earthworms. The number of days for $100 \%$ conversion of filled feed material into vermicastings was recorded. The vermicastings were harvested, and stored for further studies. The harvested 
vermicomposts were analysed for physico-chemical parameters such as $\mathrm{pH}$, electrical conductivity, organic carbon, nitrogen, phosphorous, potassium and lead.

Further a pot experiment was laid out in randomized design with three replicates at the Botanical garden of Utkal University. Altogether there were 27 pots, three replicates in each for control (C), Azolla vermicompost (AV), treated Azolla vermicompost (TAV), Pistia vermicompost (PV), treated Pistia vermicompost (TPV), Salvinia cucullata vermicompost (S.cuV), treated Salvinia cucullata vermicompost (TS.cuV), Salvinia molesta vermicompost (S.mV) and treated Salvinia molesta vermicompost (TS.mV). Green gram [Vigna radiata (L.) Wilczek] was selected and grown as the test plant. The local variety green gram seeds were collected from OUAT (Orissa University of Agriculture and Technology) Bhubaneswar and planted in each pot having three seeds.

\section{Growth and yield parameters of green gram [Vigna radiata (L.) Wilczek]}

The plant height and the number of leaves per plant were recorded at $15^{\text {th }}$ day, $30^{\text {th }}$ day, $45^{\text {th }}$ day and $60^{\text {th }}$ day from the date of sowing. The number of days for flowering, number of pod per plant, pod length, number of shoot and root branches per plant; numbers of root nodules per plant were recorded. The results were statistically analyzed.

\section{Results and discussion}

Table 1 shows the physical and chemical properties of different vermicomposts prepared from phytoremediated as well as naturally grown aquatic weeds. A significant difference was observed in each of the physico-chemical property under study in both phytoremediated and naturally prepared aquatic weed amended vermicomposts. The heavy metal $\mathrm{Pb}$ concentration was found within the permissible limit i.e., below $100 \mathrm{mg} / \mathrm{kg}$ soil. The phytoremediated Azolla-vermicompost showed high value of $\mathrm{Pb}$ concentration $(98.9 \mathrm{mg} / \mathrm{kg}$ ) as compared to other treatments. There was no significant difference in the $\mathrm{pH}$ value ranged within 7.9 to 8.3. Treated Azolla vermicompost (TAV) showed high value of electrical conductivity $(2.21 \mathrm{ds} / \mathrm{m})$.

The maximum percentage of organic carbon was recorded in TPV (2.09\%) followed by S.mV (1.92\%) and AV $(1.84 \%)$ as compared to control $(0.92 \%)$. The major macronutrients like nitrogen and phosphorous were found to be high in AV $(652.29 \mathrm{~kg} / \mathrm{ha}$ and 299.93 $\mathrm{kg} / \mathrm{ha}$ ) followed by S.mV (614.66 kg/ha and 209.08 $\mathrm{kg} / \mathrm{ha}$ ). But the potassium (K) content was found to be remarkably higher in PV (372 kg/ha) and TPV (355 $\mathrm{kg} / \mathrm{ha}$ ). It is worth mentioning that since all the desirable physico-chemical parameters under study were significantly high in both the types of vermicomposts thereby indicating their potential as novel organic manure for crop productivity.

Table 1. Physico-chemical parameters of vermicompost types.

\begin{tabular}{|c|c|c|c|c|c|c|c|c|c|}
\hline \multirow{2}{*}{ Parameters } & \multicolumn{9}{|l|}{ Treatments } \\
\hline & $\mathrm{C}$ & AV & TAV & PV & TPV & S.cuV & TS.cuV & S.mV & TS.mV \\
\hline $\mathrm{pH}$ & $8.33 \pm 0.02$ & $8.13 \pm 0.01$ & $8.02 \pm 0.01$ & $7.93 \pm 0.02$ & $8.01 \pm 0.08$ & $8.24 \pm 0.02$ & $8.32 \pm 0.01$ & $8.22 \pm 0.01$ & $8.32 \pm 0.01$ \\
\hline OC (\%) & $0.92 \pm 0.06$ & $1.84 \pm 0.01$ & $1.42 \pm 0.08$ & $1.51 \pm 0.08$ & $2.09 \pm 0.05$ & $1.34 \pm 0.02$ & $1.07 \pm 0.06$ & $1.92 \pm 0.02$ & $1.65 \pm 0.08$ \\
\hline $\mathrm{N}(\mathrm{kg} / \mathrm{ha})$ & $211 \pm 2.30$ & $652.29 \pm 0.81$ & $452.21 \pm 0.41$ & $551.22 \pm 0.36$ & $518.54 \pm 2.12$ & $528.90 \pm 1.02$ & $489.63 \pm 0.22$ & $614.66 \pm 0.72$ & $575.88 \pm 2.76$ \\
\hline $\mathrm{K}(\mathrm{kg} / \mathrm{ha})$ & $201.73 \pm 0.89$ & $298.96 \pm 0.22$ & $308.87 \pm 0.59$ & $372 \pm 0.57$ & $355.08 \pm 1.08$ & $339.23 \pm 0.39$ & $328 \pm 1$ & $296.18 \pm 0.92$ & $305.24 \pm 0.95$ \\
\hline Lead (mg/kg) & $13.26 \pm 0.17$ & $11.46 \pm 0.20$ & $99.23 \pm 0.38$ & $8.08 \pm 0.04$ & $73.97 \pm 0.71$ & $9.99 \pm 0.01$ & $48.87 \pm 0.59$ & $9.08 \pm 0.04$ & $89.43 \pm 0.29$ \\
\hline
\end{tabular}

Data represents values are mean $\pm \mathrm{SD}$; sample size $(\mathrm{n})=3$. Where, T-control, AV-Azolla vermicompost, TAV-treated Azolla vermicompost, PV- Pistia vermicompost, TPV- treated Pistia vermicompost, S.cuV-Salvinia cucullata vermicompost, TS.cuV- treated Salvinia cucullata vermicompost, S.mV- Salvinia molesta vermicompost, TS.mV-treated Salvinia molesta vermicompost; EC-Electrical conductivity; OCOrganic carbon; NPK-Nitrogen, Phosphorus, Potassium.

It was seen that the vermicomposts prepared in the present study, upon application resulted in a significant effect upon the vegetative parameters of the test crop plant i.e., Vigna radiata (green gram) as observed at $15^{\text {th }}$, $30^{\text {th }}, 45^{\text {th }}$ and $60^{\text {th }}$ day of sowing. The data presented in
Table 2 and 3 revealed the effect of different vermicompost on plant height and number of leaves per plant. The plant attained the maximum height as well as number of leaves per plant in case of Azollavermicompost (AV) followed by vermicompost of Pistia 
(PV) and the vermicompost made by utilizing Azolla after phytoremediation of $\mathrm{Pb}$ (TAV). The present findings is in conformity with the reports of Gandhi and
Sundari (2012) while studying the effect of vermicompost prepared from aquatic weeds on growth and yield of egg plant.

Table 2. The effect of different vermicomposting on plant height (in $\mathrm{cm}$ ) of Vigna radiata (L.) Wilczek at $15^{\text {th }}, 30^{\text {th }}, 45^{\text {th }}$ and $60^{\text {th }}$ day of sowing.

\begin{tabular}{lllll}
\hline Treatments & \multicolumn{3}{l}{ Plant height (in cm) at different time intervals } & \\
\cline { 2 - 5 } & $\mathbf{1 5}^{\text {th }}$ day & $\mathbf{3 0}^{\text {th }}$ day & $\mathbf{4 5}^{\text {th }}$ day & $\mathbf{6 0}^{\text {th }}$ day \\
\hline C & $5.28 \pm 0.01$ & $7.03 \pm 0.03$ & $10.26 \pm 0.03$ & $15.9 \pm 0.05$ \\
AV & $7.19 \pm 0.01$ & $10.16 \pm 0.08$ & $14.7 \pm 0.05$ & $22.83 \pm 0.06$ \\
TAV & $8.01 \pm 0.01$ & $10.56 \pm 0.03$ & $15.43 \pm 0.06$ & $26.56 \pm 0.06$ \\
PV & $6.90 \pm 0.06$ & $9.06 \pm 0.03$ & $12.86 \pm 0.08$ & $22.63 \pm 0.08$ \\
TPV & $7.30 \pm 0.03$ & $9.46 \pm 0.03$ & $13.83 \pm 0.03$ & $24.36 \pm 0.06$ \\
S.cuV & $6.03 \pm 0.03$ & $8.3 \pm 0.05$ & $11.9 \pm 0.05$ & $18.93 \pm 0.03$ \\
TS.cuV & $6.43 \pm 0.03$ & $8.86 \pm 0.08$ & $12.33 \pm 0.06$ & $19.46 \pm 0.03$ \\
S.mV & $5.76 \pm 0.03$ & $7.5 \pm 0.05$ & $10.93 \pm 0.03$ & $18.33 \pm 0.08$ \\
TS.mV & $6.03 \pm 0.03$ & $7.4 \pm 0.05$ & $11.33 \pm 0.08$ & $18.7 \pm 0.05$ \\
\hline
\end{tabular}

Table 3. The effect of different vermicompost on number of leaves per plant of Vigna radiata (L.) Wilczek.

\begin{tabular}{lllll}
\hline Treatments & \multicolumn{4}{l}{ Number of leaves at different time intervals } \\
\cline { 2 - 5 } & $\mathbf{1 5}^{\text {th }}$ day & $\mathbf{3 0}^{\text {th }}$ day & $\mathbf{4 5}^{\text {th }}$ day & $\mathbf{6 0}^{\text {th }}$ day \\
\hline C & $4.66 \pm 0.57$ & $8.33 \pm 0.33$ & $12 \pm 0.57$ & $14.66 \pm 0.33$ \\
AV & $10.66 \pm 0.88$ & $16.33 \pm 0.33$ & $19.33 \pm 0.33$ & $223.33 \pm 0.66$ \\
TAV & $11.33 \pm 0.33$ & $16 \pm 0.57$ & $21.66 \pm 0.66$ & $28 \pm 1$ \\
PV & $8 \pm 0$ & $14.66 \pm 0.33$ & $16.66 \pm 0.66$ & $20.66 \pm 0.33$ \\
TPV & $8.33 \pm 0.66$ & $17 \pm 0$ & $18.33 \pm 0.33$ & $24.66 \pm 0.33$ \\
S.cu.V & $6.33 \pm 0.33$ & $13.3 \pm 0.33$ & $15.66 \pm 0.66$ & $19 \pm 0.57$ \\
TS.cuV & $7.66 \pm 0.57$ & $14.3 \pm 0.33$ & $17.66 \pm 0.66$ & $20.33 \pm 0.33$ \\
S.mV & $5.33 \pm 0.88$ & $10.66 \pm 0.33$ & $12.33 \pm 0.66$ & $16 \pm 0$ \\
TS.mV & $8.66 \pm 0.33$ & $12.6 \pm 0.33$ & $15 \pm 0$ & $17.66 \pm 0.33$ \\
\hline
\end{tabular}

Table 4. The effect of vermicomposting on various growth parameters of Vigna radiata (L.) Wilczek.

\begin{tabular}{llllllll}
\hline Treatments & $\begin{array}{l}\text { No of } \\
\text { flowers } \\
\text { /plant }\end{array}$ & $\begin{array}{l}\text { Number of } \\
\text { pod/plant }\end{array}$ & $\begin{array}{l}\text { Pod length } \\
\text { (in cm) }\end{array}$ & $\begin{array}{l}\text { Number of } \\
\text { shoot } \\
\text { branches/ } \\
\text { plant }\end{array}$ & $\begin{array}{l}\text { Number of } \\
\text { root branches/ } \\
\text { Plant }\end{array}$ & $\begin{array}{l}\text { Number of root nodules } \\
\text { /plant }\end{array}$ & Medium \\
\hline C & $5.33 \pm 0.33$ & $3 \pm 0.57$ & $6.80 \pm 0.17$ & $7.66 \pm 1.2$ & $10.33 \pm 0.88$ & $6.33 \pm 0.88$ & $10.33 \pm 0.33$ \\
AV & $12 \pm 0.57$ & $11.33 \pm 0.33$ & $9.5 \pm 0.25$ & $11.66 \pm 0.88$ & $15.06 \pm 0.88$ & $14.66 \pm 1.2$ & $12.66 \pm 1.85$ \\
TAV & $8.66 \pm 0.88$ & $9 \pm 0.57$ & $8.9 \pm 0.11$ & $6 \pm 0.57$ & $10 \pm 0.57$ & $5.33 \pm 1.2$ & $11.66 \pm 0.66$ \\
PV & $9.4 \pm 0.3$ & $9.33 \pm 0.33$ & $9.0 \pm 0.12$ & $9.66 \pm 0.66$ & $14 \pm 1$ & $14.33 \pm 1.76$ & $5.33 \pm 0.33$ \\
TPV & $10.26 \pm 0.88$ & $6 \pm 0.57$ & $8.33 \pm 0.28$ & $8 \pm 0.57$ & $9.33 \pm 0.88$ & $8 \pm 1$ & $7.66 \pm 1.2$ \\
S.cuV & $9.16 \pm 0.16$ & $6 \pm 1$ & $7.96 \pm 0.12$ & $7.33 \pm 1.2$ & $10.66 \pm 0.33$ & $11 \pm 1.15$ & $4.33 \pm 1.2$ \\
TS.cuV & $7 \pm 0.57$ & $4.33 \pm 0.66$ & $7.2 \pm 0.15$ & $7.33 \pm 0.33$ & $7.66 \pm 0.66$ & $4.33 \pm 0.66$ & $10.66 \pm 0.33$ \\
S.mV & $7.43 \pm 0.44$ & $3.66 \pm 0.88$ & $7.37 \pm 0.17$ & $7 \pm 0.57$ & $10.33 \pm 0.66$ & $6.66 \pm 0.88$ & $11.33 \pm 1.33$ \\
TS.mV & $6.06 \pm 0.33$ & $3 \pm 1$ & $7.13 \pm 0.13$ & $4.66 \pm 0.66$ & $7.66 \pm 1.33$ & $3 \pm 0.57$ & $7 \pm 1.15$ \\
\hline
\end{tabular}

Table 4 reveals the effect of different vermicompost on shoot and root branches per plant, number of root nodules per plant, number of flowers and pod per plant, pod length etc. The highest number of shoot branches was recorded in Azolla-vermicompost (AV) followed by PV, S.cuV, and TPV including control. Likewise maximum root branches was observed in Azollavermicompost (15) followed by Pistia-vermicompost (14) as compared to others. Arancon et al. (2006) observed that application of vermicompost can induce plant growth hormones such as auxins and humic acid which is produced by the microorganisms. Atiyeh et al. (2000a) reported the increase in rates of shoot and root growth in response to different doses of application of vermicompost. Legume nodules are spherical or cylindrical growth formed in the plants roots as a result of an infection by bacteria (Stricter, 1995). The bacteria like Rhizobium living symbiotically with leguminous 
plants can fix the atmospheric nitrogen in its root nodules (Jain, 2000). During the present experiment highest numbers of root nodules were recorded to be formed in the test crop upon application of AV (14 medium, 12 small) as compared to control (6 medium, 10 small).

It was also observed that the number of flowers per plant was reduced in TS.mV (6) as compared to PV (10) and AV (12). The highest number of pods per plant was recorded in AV (11) followed by TAV (9), PV (9), S.mV (7) and control (3). The maximum value of pod length was seen in the experimental plant when applied with AV $(9.5 \mathrm{~cm})$ followed by PV $(9.0 \mathrm{~cm})$, TAV $(8.9 \mathrm{~cm})$ and control $(6.8 \mathrm{~cm})$. A similar trend in the number of fruits per plant and fruit length was observed in egg plant treated with vermicomposts prepared from different aquatic weeds (Gandhi and Sundari, 2012). Nuruzzaman et al., (2003) observed the significant increase in growth and yield parameters of okra when applied biofertilizers with cow-dung.

\section{Conclusion}

Agriculture in modern time is getting more and more dependent upon the steady supply of artificial fertilizer with the introduction of green revolution technologies (Dominguez et al., 1997). Vermicompost is one of the best plant growth regulating substances including growth hormones and humic acids which are probably responsible for the increase in the rate germination, growth and yield of plant (Atiyeh et al., 2000b). Vermicomposts are cost effective, ecofriendly and also act as a source of plant nutrients to supplement chemical fertilizers in a sustainable way of agricultural practice in India. These organic manures indeed enhance crop productivity through improved supplies of nutrients as observed in case of pulse crop during the present investigation. In recent times, it has become difficult to manage the aquatic weeds in lotic and lentic types of water bodies. These aquatic weeds have a tremendous potential of accumulating heavy metals including $\mathrm{Pb}$ for which they can be exploited for phytoremediation of water contaminated with heavy metals. However, disposal of these phytoremediated biomass are usually either utilized for land fill purpose or they are burnt in a furnace. The present investigation confirmed the conversion of this phytoremediated aquatic weeds biomass into vermicompost which can be considered as an effective and ecofriendly technology for sustainable agriculture. This study also highlights the management of the rapid growth of aquatic weeds by utilizing them for bioremediation as well as the production of vermicomposts. These types of vermicompost can fertilize the crops for sustainable productivity, particularly pulse crops like green gram.

\section{Conflict of interest statement}

Authors declare that they have no conflict of interest.

\section{Acknowledgement}

The authors are thankful to the Head of the P.G. Department of Botany, Utkal University, Vani Vihar, Bhubaneswar, Odisha for providing necessary laboratory facilities.

\section{References}

Angle, J.S., Linacre, N.A., 2005. Metal phytoextraction-A survey of potential risks. In. J. Phytoremed. 7, 241-254.

Atiyeh, R.M., Arancon, N.Q., Edwards, C.A., Metzger, J.D., 2000a. Influence of Earthworm processed pig manure on the growth and yield of green house tomatoes. Bioresour. Technol. 75, 175-180.

Atiyeh, R.M., Subler, S., Edwards, C.A., Bachan, G., Metzger, J.D., Shuster, W., 2000b. Effects of vermicompost and compost on plant growth in horticultural container media and soil. Pedobiol. 44, 579-590.

Arancon, N.Q., Edwards, C.A., Lee, S., Byrne, R., 2006. Effects of humic acid from vermicompost on plant growth. Eur. J. Soil Biol. 46, 65-69.

Central Pollution control Board (CPCB), 2008. Status of water quality in India 2007. CPCB, New-Delhi, India.

Divya, S., Richa, G., Archana, T., 2011. Phytoremediation of lead from wastewater using aquatic plants. Int. J. Biomed. Res. 2(7), 411-421.

Dominguez, J., Edwards, C. A., Subler, S., 1997. A comparison of vermicomposting and composting. Biocycle. 38, 57-59.

EI-Shaikh, K.A.A., Mohammed, M.S., 2009. Enhancing fresh and seed yield of okra and reducing chemical phosphorous fertilizer via using VA Mycorrhizal inoculants. World J. Agric. Sci. 5, 810-818.

Gandhi, A., Sundari, U. S., 2012. Effect of vermicompost prepared from aquatic weeds on growth and yield of eggplant (Solanum melongena L.). J. Biofert. Biopestic. 3, 128.

Hinchman, R. R, Negri, M. C., Gatliff, E. G., 1996. Phytoremediation: using green plants to clean up contaminated soil, ground water and waste water, downloaded at: http://citeseerx.ist.psu.edu/viewdoc/ download? doi=10.1.1.26.2529\&rep=rep1\&type $=$ pdf

Hussain, J., Rehman, N. U., Khan, A. L., Hussain, H., Alharrasi, A., 2011. Determination of macro and micronutrients and Nutritional prospects of six vegetables species of mardan. Pak. J. Bot. 43, 2829-2833. 
Jain, V. K., 2000. In: Fundamentals of Plant Physiology. S. Chand and Co. Ltd., New Delhi.

Kale, R. D., Mallesh, B. C., Kubra, B., Bagyaraj, D. J., 1992. Influence of vermicompost application on the available macronutrients and selected microbial populations in a paddy field. Soil Boil. Biochem. 24, 1317-1320.

Leela, K., Kasturi, G., Satyawati, S., 2010. Effect of pH and lead concentration on phytoremoval of lead from lead contaminated water. Am. Euras. J. Agric. Environ. Sci. 7(5), 542-550.

Mishra, M., Pradhan, C., Satapathy, K. B., 2015. Decontamination of Lead from aquatic environment by exploitation of floating macrophyte Azolla microphylla Kauf. IOSR J. Environ. Sci. Toxicol. Food Technol. 12(8),
17-23.

Nuruzzaman, M., Ashrafuzzaman, M., Islam, M. Z., Islam, M. R., 2003. Field efficiency of biofertilizers on the growth of okra (Abelmoschus esculentus [L.] Moench). J. Plant Nutr. Soil Sci. 166, 764-770.

Rai, L. C., Gaur, J. P., Kumar, H. D., 1981. Phycology and heavy metal pollution. Biol. Rev. Cambridge Philosoph. Soc. 56, 99-151.

Saminathan, B., 2013. Mercury induced changes in germination and biochemical analysis of green gram. Int. J. Environ. Biol. 3(4), 151-156.

Stricter, G. J., 1995. A new model for the rapid effects of noninvasive treatments on nitrogenise and respiratory activity in legume nodules. J. Theor. Biol. 174, 441-452.

\section{How to cite this article:}

Mishra, M., Mohapatra, A., Satapathy, K. B., 2016. A Comparative study of vermicompost prepared from phytoremediated and naturally grown aquatic weeds on growth and yield of green gram [Vigna radiata (L.) Wilczek]. Int. J. Curr. Res. Biosci. Plant Biol. 3(7), 104-109. doi: http://dx.doi.org/10.20546/ijcrbp.2016.307.015 